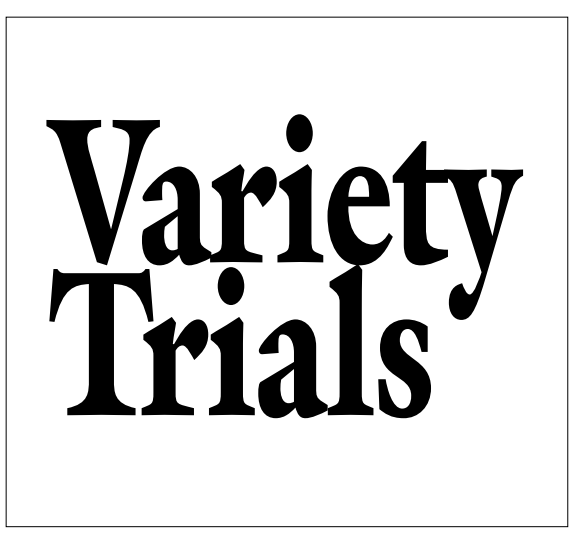

\section{Change over Time in Quality and Cover of Various Turfgrass Species and Cultivars Maintained in Shade}

\section{D.S. Gardner ${ }^{1}$ and J.A. Taylor ${ }^{2}$}

\author{
Additional indeX words. Festuca \\ arundinacea, Festuca rubra, Festuca \\ rubra var. commutata, Festuca \\ longifolia, Lolium perenne, Poa \\ pratensis, Poa trivialis, cultivar \\ selection
}

\begin{abstract}
Summary. In 1992, a cultivar trial was initiated in Columbus, Ohio to evaluate differences in establishment and long-term performance of cultivars of tall fescue (Festuca arundinacea), creeping red fescue ( $F$. rubra), chewings fescue (F. rubra ssp. fallax), hard fescue (F. brevipila), kentucky bluegrass (Poa pratensis), rough bluegrass (P. trivialis), and perennial ryegrass (Lolium perenne) under low maintenance conditions in a shaded environment. Fertilizer and

\footnotetext{
Deprtment of Horticultural and Crop Science, 2021 Coffey Road, The Ohio State University, Columbus, $\mathrm{OH}$ 43210-1086.

Salaries and research support provided by state and federal funds appropriated to the Ohio Agricultural Research and Development Center, Ohio State Univ. Manuscript HCS 01-3.

${ }^{1}$ Assistant professor of turfgrass science. To whom requests for reprints should be addressed; e-mail gardner.254@osu.edu.

${ }^{2}$ Research associate and manager of The Ohio Turfgrass Foundation Research and Education Facility.
}

supplemental irrigation were applied until 1994 to establish the grasses, after which no supplemental irrigation, or pesticides were applied and fertilizer rates were reduced to $\mathbf{4 8 . 8}$ $\mathrm{kg} \cdot \mathrm{ha}^{-1}\left(1 \mathrm{lb} / 1000 \mathrm{ft}^{2}\right)$ of $\mathrm{N}$ per year. Percentage cover and overall quality data were collected in 2000 and compared with data collected in 1994. Initial establishment success does not appear to be a good predictor of longterm success of a cultivar in a shaded environment. There was some variability in cultivar performance under shade within a given turfgrass species. The tall fescue cultivars, as a group, had the highest overall quality and percentage cover under shade, followed by the fine fescues, kentucky bluegrass, rough bluegrass, and perennial ryegrass cultivars.

$\mathrm{R}$ ecommending a single turfgrass species, cultivar, or blend to thrive in a particular shaded site is challenging. Shaded areas vary in sunlight availability, soil type and nutrient status, moisture holding capacity, drainage, and air circulation. Light interception usually becomes the most important limiting factor when other factors such as nutrients and water are optimized for growth (Dudeck and Peacock, 1992).

It is estimated that about 20 to $25 \%$ of all turfgrass is maintained under some degree of shading caused either by buildings and other structures, trees, and shrubs (Beard, 1973). Few turfgrass species are adapted for growth in a shaded environment (Wilkinson et al., 1975). The success of a turfgrass in a shaded area is influenced not only by the ability to cope with the reduction in available light, but also tree root competition for water and nutrients and the plants ability to resist the increase in potential disease activity. Previous research suggests that red fescue is more tolerant of shade than kentucky bluegrass due primarily to structural features that increase resistance to disease infection (Wilkinson et al., 1975).

Tall fescue cultivars have acceptable to good performance in $70 \%$ tree shade (Wu et al., 1985). The general consensus, however, is that among the cool season grasses, the fine fescueshave superiorshade tolerance, while tall fescue, rough bluegrass, and creeping bentgrass have good shade tolerance. Perennial ryegrass and kentucky bluegrass have fair to poor shade tolerance (Beard, 1973).

The objective of this study was to evaluate the long-term persistence of turfgrass species and cultivars in shaded conditions. Inputs of fertilizer, supplemental irrigation, and pesticides were held to a minimum so that the evaluation could reflect conditions and management intensity typical of golf course roughs, parks, and recreational facilities.

\section{Materials and methods}

The trial was established on 30 Sept. 1992 at the Ohio State Turfgrass Foundation Research and Education Center, Columbus, Ohio. The soil was a Brookston silty clay loam with a $\mathrm{pH}$ of 7.5 and $90 \mathrm{~g} \cdot \mathrm{kg}^{-1}(9 \%)$ of organic matter. Soil test results indicated an adequate phosphorus $(\mathrm{P})$ level for turfgrass $\left[10 \mathrm{mg} \cdot \mathrm{kg}^{-1}(20 \mathrm{lb} /\right.$ acre $)$ of $\mathrm{P}$ ], and a low level of potassium $(\mathrm{K})$ for turfgrass [12l mg. $\mathrm{kg}^{-1}$ (242 lb/acre) of $\mathrm{K}$ ], using the Bray-Pl extraction method for phosphorus and the ammonium acetate extraction method for potassium (Tisdale et al., 1993).

Thirty cultivars were established on three replicate plots. Each plot was $1.9 \mathrm{~m}^{2}\left(20 \mathrm{ft}^{2}\right)$ and plots were arranged in a randomized complete block design with three rows of 10 plots per block. The three blocks were arranged from east to west and placed in the center of a 9-m (29-ft) wide strip of turf that lies between, and under the canopy of, a single row of mature trees [primarily sugar maple (Acer saccharinum) and sycamore (Platanus occidentalis)] and a grove of mature woods. The area where the trial was established varies from partial sun to deep shade (40 to 300 $\left.\mu \mathrm{mol} \cdot \mathrm{m}^{-2} \cdot \mathrm{s}^{-1}\right)$. Shade level across the area of the study was uniform throughout the day and shade variability within individual plots exceeded the shade variability between plots within a replication. However, shade density was generally higher in the first replication, due to two additional trees placed between the tree hedge and the research plots. Blocking was across this shade variability. Cultivars and species selected for this trial represent a broad cross section of the grasses available for establishing as turfgrass as well as then-experimental cultivars of several seed companies (Table 1).

One inch of topsoil was added before establishment. All entries were seeded by hand at the recommended seeding rate for the species (Table 1 ). Nitrogen was applied as urea $(46 \mathrm{~N}-0 \mathrm{P}-$ $0 \mathrm{~K})$ at a rate of $97.6 \mathrm{~kg} \cdot \mathrm{ha}^{-1}(2 \mathrm{lb} / 1000$ $\mathrm{ft}^{2}$ ) of $\mathrm{N}$ during the first year (August 1992 - August 1993) of the trial and at a rate of $48.8 \mathrm{~kg} \cdot \mathrm{ha}^{-1}\left(\mathrm{llb} / 1000 \mathrm{ft}^{2}\right)$ of 
$\mathrm{N}$ in subsequent years. No other fertilizer was applied. The turfgrass was mowed at a $8.9-\mathrm{cm}(3.5$-inch) height. Supplemental irrigation was provided August 1992 to May 1993 to encourage growth. Supplemental irrigation was provided four times during Summer 1993 to prevent stress to the trial. No other supplemental irrigation was provided. With the exception of a single application of a contact fungicide to control brown patch on the tall fescues in June 1994, no pesticides were used.

Estimates of turfgrass visual quality and percentage cover were made in June 1994 and September 2000. Turfgrass visual quality was evaluated on a scale of $l$ to 9 where $l=$ poorest quality, $6=$ lowest acceptable quality, and $9=$ best quality based on overall color and density. The 2000 data were analyzed using the general linear models (GLM) procedure of SAS (SAS Institute, 1990). Data collected in July, Aug., and Sept. were pooled and analyzed as a randomized complete block design with cultivars nested within species. Orthogonal contrasts were used to test hypothesis of species performance. Fishers's least significant difference (LSD) test was used to compare means over all cultivars.

\section{Results}

Percent cover. In the establishment year (August 1992 to August 1993), best germination and cover were achieved by the ryegrasses, followed by the fine fescues, tall fescues, and rough bluegrass (data not shown). Poorest germination and cover were recorded for the kentucky bluegrasses. In the second year (August 1993 to August 1994), the ryegrasses still had the highest cover, followed by the fine fescues, tall fescues, and rough bluegrass. Kentucky bluegrass had some lateral growth, but still rated poorly in cover.

The tall fescue cultivars maintained the highest cover (Table 2). Most cultivars maintained $63 \%$ to $87 \%$ cover and increased in percentage cover when compared to measurements taken in 1994 (Table 3). The variability in percentage cover among the tall fescue cultivars tested was nonsignificant, with the exception of 'LDTF II-92', which had 50\% cover in 2000, a loss of $12 \%$ compared to 1994 .

The fine fescues (chewings fescue, red fescue, and hard fescue) maintained higher cover during 2000 than did kentucky bluegrass, rough bluegrass, or perennial ryegrass (Table 2 ). The chewing fescues maintained better cover than the red fescues, and the red fescues maintained better coverage than the hard fescues. The chewings fescue cultivars 'RUCF-92' and 'Jamestown II' produced cover that was comparable to the best tall fescue cultivars (Table 3 ).

The kentucky bluegrasses maintained higher cover during 2000 than did the perennial ryegrasses and rough bluegrass. 'Coventry' produced significantly better cover than did '4 Aces' or 'Blacksburg', but was significantly lower than the top performing tall fescues. No differences between the ryegrasses and rough bluegrasses were observed. The perennial ryegrasses had some of the highest percentage cover estimates during 1994. However, the percentage cover for the perennial ryegrasses and rough bluegrass decreased $45 \%$ to $70 \%$ during the study period.

Overall Quality. In 1993, most of the grasses had acceptable quality (data not shown). The bluegrasses received the lowest ratings due to poor cover, and the fine fescues had poor color. Rough bluegrass had high quality in 1993 but declined in 1994 due to poor color and loss of cover. The fine fescues scored higher in quality in 1994. The tall fescues had good color, but scored lower in 1994 due to loss of cover caused by brown patch (Rhizoctonia solani).

During 2000, the tall fescue entries maintained higher overall visual quality than the other species in the trial (Table 4). Tall fescue has a more course leaf texture, but the density, cover, and color were superior to the other grasses tested. Few differences among the cultivars were observed (Table 5). However, 'Rebel 3D' and 'LDTF II-92' had significantly lower quality compared to 'Tribute' which had the highest overall quality among the cultivars tested.

The fine fescues outperformed the kentucky bluegrasses, perennial ryegrasses, and rough bluegrass. No differences between the chewings fescue, hard fescue, or red fescue were observed. Several of the fine fescues had lower overall quality in 2000 compared to 1994. Among the fine fescues, 'RUCF-92', 'Jamestown II', 'Molinda', and 'SCR-92' had overall quality comparable to some of the tall fescues. However, only 'RUCF-92' was comparable to 'Tribute' tall fescue.

The kentucky bluegrasses, perennial ryegrasses, and rough bluegrass had the lowest overall quality in 2000 . The kentucky bluegrasses evaluated were similar in quality to the ryegrasses and rough bluegrass. Several of these cultivars had decreased over time in quality since 1994.

\section{Discussion}

Long term quality and cover of the tall fescue cultivars observed in this study may be due to their greater adaptability to extreme climatic conditions than the other species in the study tolerate. Columbus, Ohio is slightly north of what is traditionally considered the transition zone [along and roughly 100 miles $(161 \mathrm{~km})$ either side of a line from Washington D.C. to St. Louis to Topeka, Kans.]. However, temperature and moisture extremes, particularly in the summer, may have favored the tall fescue in this trial (Turgeon, 1991).

During the study period, the tall fescues gained in overall quality and cover. However, many of the kentucky bluegrass, perennial ryegrass, and rough bluegrass cultivars that had established well decreased in overall cover and quality during the study period. Since no additional supplemental irrigation and only minimal fertilizer was applied after the first year, tall fescue, with its deeper and more extensive root system (McCarty, 2001), may have had a competitive advantage over the other species for nutrient acquisition.

The results of this study were consistent with previous suggestions that tall fescue has a long-term competitive advantage that offsets the rapid initial establishment of other species such as perennial ryegrass (Engel, 1974; Turgeon, 1991). The tall fescues had the highest quality, primarily due to darker green color, cover, and density (Fig. 1A). The fine fescues maintained acceptable cover, but were more subject to encroachment by weeds and other grasses and had a lighter green color (Fig. 1B). The other species tested did not maintain acceptable stand density and were subject to extensive weed encroachment (Fig. 1C).

Specific cultivar recommendations for turfgrass in shade was not the objective of this study. Some of the cultivars tested were experimental in 1992 and never released by the registrant. Also, variability in cultivar performance would be expected in different levels of shade or in different soils, locations, etc. However, in this study, we note that the long-term performance of the tall fescue cultivars tested was superior to the other grasses (Fig. 1). Also, initial establishment success does not appear to 
Table 1. Species and cultivars of turfgrass evaluated for long-term performance in shaded conditions in Columbus, Ohio.

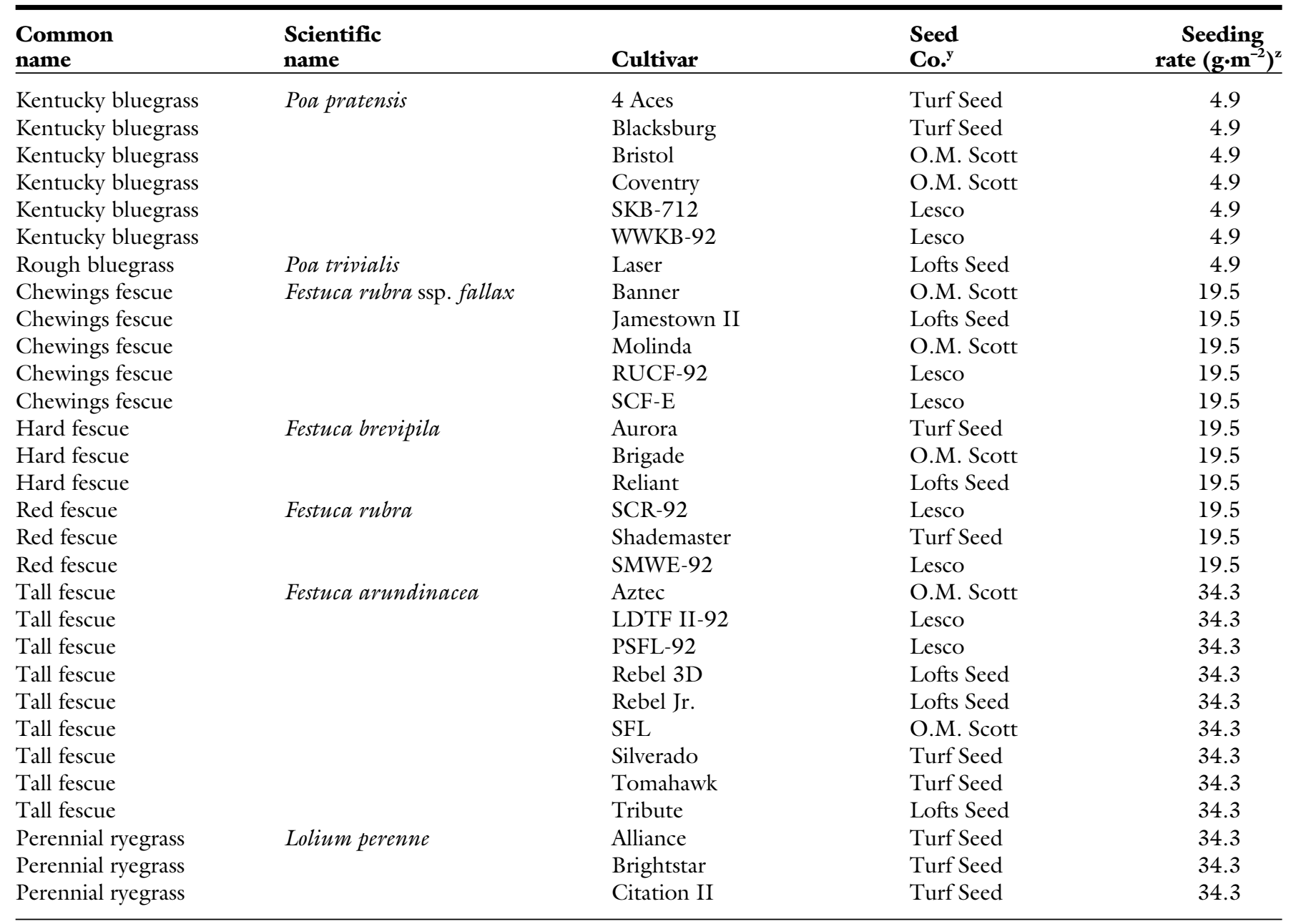

${ }^{\mathrm{z}} 4.9 \mathrm{~g} \cdot \mathrm{m}^{2}=1 \mathrm{lb} / 1000 \mathrm{ft}^{2}$.

yTurf Seed = Turf-Seed Inc., Hubbard, Ore.; Lofts Seed = Lofts Seed, a division of Budd Seed, Winston-Salem, N.C; Lesco = Lesco, Inc., Rocky River, Ohio; O.M. Scott = The Scotts Company, Marysville, Ohio.

Table 2. Mean percentage cover estimates during 2000 for various turfgrass species grown in moderate shade in Columbus, Ohio.

\begin{tabular}{|c|c|c|c|}
\hline Species & Sultivars tested (no.) & Mean cover $(\%)^{\mathrm{z}}$ & \\
\hline Chewings fescue & 5 & 62.7 & \\
\hline Kentucky bluegrass & 6 & 32.5 & \\
\hline Hard fescue & 3 & 27.2 & \\
\hline Rough bluegrass & 1 & 10.0 & \\
\hline \multicolumn{4}{|l|}{ Analysis of variance } \\
\hline Source & df & MS & $P>\mathrm{F}$ \\
\hline Replication & 2 & 2064 & $<0.01$ \\
\hline Entry & 29 & 1920 & $<0.01$ \\
\hline Species & 6 & 7566 & $<0.01$ \\
\hline Tall fescue vs. other species & 1 & 23469 & $<0.01$ \\
\hline Kentucky bluegrass vs. ryegrass and rough bluegrass & 1 & 3920 & $<0.01$ \\
\hline Perennial ryegrass vs. rough bluegrass & 1 & 3 & 0.93 \\
\hline Cultivar (species) & 23 & 447 & 0.15 \\
\hline Error & 58 & 318 & \\
\hline
\end{tabular}

${ }^{2}$ Values are the average of visual estimates of three replicate plots for each cultivar evaluated. 
Table 3. Change in percentage cover of turfgrass cultivars maintained in a shaded location from 1994-2000 in Columbus, Ohio.

\begin{tabular}{|c|c|c|c|c|}
\hline \multirow[b]{2}{*}{ Cultivar } & \multirow[b]{2}{*}{ Species } & \multicolumn{2}{|c|}{ Mean cover $(\%)$} & \multirow[b]{2}{*}{ Change (\%) } \\
\hline & & 2000 & 1994 & \\
\hline Tribute & Tall fescue & 87 & 73 & 14 \\
\hline RUCF-92 & Chewings fescue & 87 & 79 & 8 \\
\hline SFL & Tall fescue & 80 & 38 & 42 \\
\hline Rebel 3D & Tall fescue & 80 & 48 & 32 \\
\hline Tomahawk & Tall fescue & 80 & 85 & -5 \\
\hline PSFL-92 & Tall fescue & 77 & 77 & 0 \\
\hline Rebel Jr. & Tall fescue & 73 & 63 & 10 \\
\hline Jamestown II & Chewings fescue & 70 & 60 & 10 \\
\hline Silverado & Tall fescue & 67 & 55 & 12 \\
\hline Aztec & Tall fescue & 63 & 58 & 5 \\
\hline SCR-92 & Red fescue & 57 & 62 & -5 \\
\hline Banner & Chewings fescue & 53 & 57 & -4 \\
\hline Molinda & Chewings fescue & 53 & 60 & -7 \\
\hline SMWE-92 & Red fescue & 50 & 60 & -10 \\
\hline LDTF II-92 & Tall fescue & 50 & 62 & -12 \\
\hline Coventry & Kentucky bluegrass & 47 & 32 & 15 \\
\hline SKB-712 & Kentucky bluegrass & 43 & 20 & 23 \\
\hline Shademaster & Red fescue & 43 & 68 & -25 \\
\hline SCF-E & Chewings fescue & 43 & 73 & -30 \\
\hline Brigade & Hard fescue & 40 & 45 & -5 \\
\hline WWKB-92 & Kentucky bluegrass & 37 & 10 & 27 \\
\hline Bristol & Kentucky bluegrass & 33 & 28 & 5 \\
\hline Aurora & Hard fescue & 22 & 67 & -45 \\
\hline Reliant & Hard fescue & 20 & 73 & -53 \\
\hline 4 Aces & Kentucky bluegrass & 18 & 27 & -9 \\
\hline Blacksburg & Kentucky bluegrass & 17 & 17 & 0 \\
\hline Laser & Rough bluegrass & 13 & 58 & -45 \\
\hline Brightstar & Perennial ryegrass & 13 & 75 & -62 \\
\hline Alliance & Perennial ryegrass & 7 & 72 & -65 \\
\hline Citation II & Perennial ryegrass & 7 & 77 & -70 \\
\hline $\operatorname{LSD}_{0.05}{ }^{\mathrm{z}}$ & & 29 & & \\
\hline
\end{tabular}

${ }^{\mathrm{z} A c c o r d i n g}$ to Fisher's least significant difference test $(\mathrm{n}=3)$.

Table 4. Mean monthly turfgrass visual quality ratings during 2000 for various turfgrass species grown in moderate shade in Columbus, Ohio.

Common name Cultivars tested (no.) Mean quality rating

Tall fescue

Chewings fescue

Hard fescue

Red fescue

Kentucky bluegrass

Rough bluegrass

Perennial ryegrass

Analysis of variance

$\begin{array}{ll}9 & 6.1 \\ 5 & 4.6 \\ 3 & 4.2 \\ 3 & 4.1 \\ 6 & 3.7 \\ 1 & 3.6 \\ 3 & 2.9\end{array}$

\begin{tabular}{lrrr} 
Source & df & MS & P F \\
\hline Replication & 2 & 5 & $<0.01$ \\
Entry & 29 & 19 & $<0.01$ \\
Species & 6 & 90 & $<0.01$ \\
Tall fescue versus Other species & 1 & 13 & $<0.01$ \\
Fine fescues versus bluegrasses and ryegrass & 1 & 2 & 0.01 \\
Chewings fescue versus hard fescue and red fescue & 1 & 0 & 0.94 \\
Hard fescue versus red fescue & 1 & 3 & 0.08 \\
Kentucky bluegrass versus ryegrass and rough bluegrass & 1 & 1 & 0.30 \\
Perennial ryegrass versus rough bluegrass & 1 & 2 & 0.05 \\
Cultivar (species) & 23 & 1 &
\end{tabular}

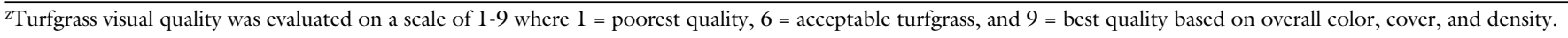


Table 5. Change in overall quality of turfgrass cultivars maintained in a shaded location from 1994 to 2000 in Columbus, Ohio.

\begin{tabular}{|c|c|c|c|c|}
\hline \multirow[b]{2}{*}{ Cultivar } & \multirow[b]{2}{*}{ Species } & \multicolumn{2}{|c|}{ Mean quality rating ${ }^{\mathrm{z}}$} & \multirow{2}{*}{$\begin{array}{c}\text { Change } \\
\text { 1994-2000 }\end{array}$} \\
\hline & & 2000 & 1994 & \\
\hline Tribute & Tall fescue & 7.2 & 5.8 & 1.4 \\
\hline SFL & Tall fescue & 6.3 & 4.0 & 2.3 \\
\hline Rebel Jr. & Tall fescue & 6.3 & 6.3 & 0.0 \\
\hline Tomahawk & Tall fescue & 6.2 & 7.8 & -1.6 \\
\hline Silverado & Tall fescue & 5.6 & 6.0 & -0.4 \\
\hline Rebel 3D & Tall fescue & 5.4 & 4.2 & 1.2 \\
\hline LDTF II-92 & Tall fescue & 5.1 & 6.3 & -1.2 \\
\hline Jamestown II & Chewings fescue & 4.9 & 6.3 & -1.4 \\
\hline Molinda & Chewings fescue & 4.7 & 7.5 & -2.8 \\
\hline SCF-E & Chewings fescue & 4.2 & 7.7 & -3.5 \\
\hline Brigade & Hard fescue & 4.1 & 6.0 & -1.9 \\
\hline Reliant & Hard fescue & 4.1 & 6.5 & -2.4 \\
\hline Brightstar & Perennial ryegrass & 4.1 & 7.0 & -2.9 \\
\hline SMWE-92 & Red fescue & 4.1 & 8.0 & -3.9 \\
\hline SKB-712 & Kentucky bluegrass & 3.9 & 2.5 & 1.4 \\
\hline WWKB-92 & Kentucky bluegrass & 3.9 & 3.0 & 0.9 \\
\hline Shademaster & Red fescue & 3.8 & 6.3 & -2.5 \\
\hline Laser & Rough bluegrass & 3.6 & 5.9 & -2.3 \\
\hline Banner & Chewings fescue & 3.4 & 5.7 & -2.3 \\
\hline Blacksburg & Kentucky bluegrass & 2.9 & 3.3 & -0.4 \\
\hline 4 Aces & Kentucky bluegrass & 2.8 & 5.0 & -2.2 \\
\hline
\end{tabular}

zTurfgrass visual quality was evaluated on a scale of 1 to 9 where 1 = poorest quality, $6=$ acceptable turfgrass, and $9=$ best quality based on overall color, cover, and density. yAccording to Fisher's least significant difference test $(n=3)$.
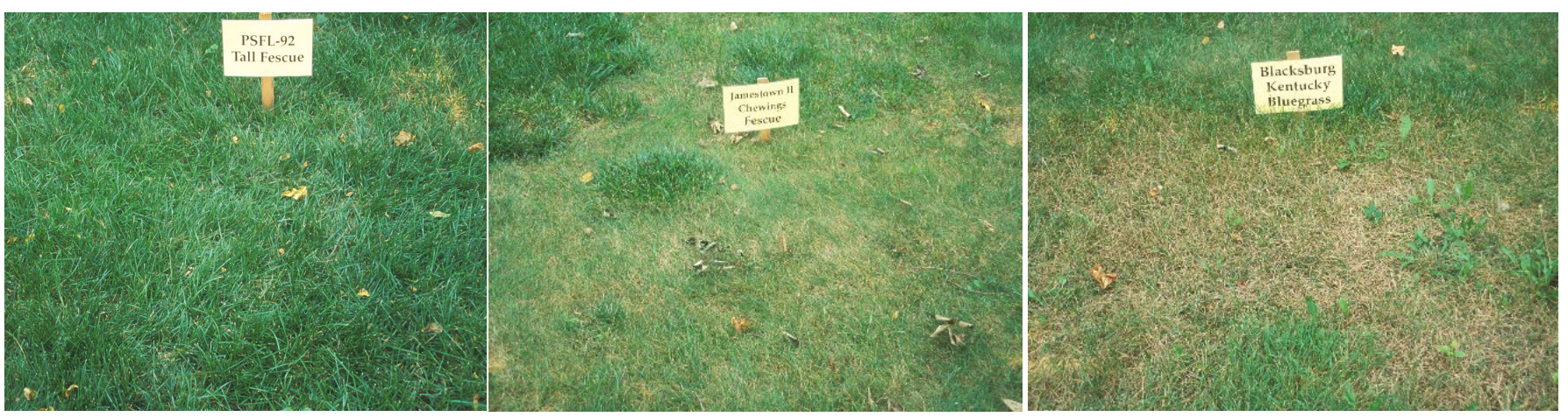

Fig. 1. Appearance of a representative tall fescue (left), fine fescue (middle), and kentucky bluegrass (right) cultivar after establishment and maintenance under moderate shade for the 8-year period 1992-2000 in Columbus, Ohio. Signs are printed on $28 \times 21.5$ - $\mathrm{cm}(11.0 \times 8.5$-inch)

berdstock. cess of a cultivar. Finally, there appears to be some variability in cultivar performance under shade within a given turfgrass species.

\section{Literature cited}

Beard, J.B. 1973. Turfgrass: Science and culture. Prentice Hall, Englewood Cliffs, N.J.

Dudeck, A.E. and C.H. Peacock. 1992. Shade and turfgrass culture, p. 269-284. In: D.V. Waddington, R.N. Carrow, and R.C. Shearman (eds.). TurfgrassAgron. Monogr. 32. ASA-CSSA-SSSA, Madison, Wis.

Engel, R.E. 1974. Influence of nitrogen fertilization on species dominance in turfgrass mixtures, p. 104111. In: E.C. Roberts (ed.). Proc $2^{\text {nd }}$ Intl. Turf Res. Conf., Blacksburg, Va.

McCarty, L.B. 2001. Best golf course management practices. Prentice Hall, Englewood Cliffs, N.J.

SAS Institute. 1990. SAS/STAT user's guide. vol. 2. $4^{\text {th }}$ ed. SAS Inst., Cary, N.C.
Tisdale, S. L., W.L. Nelson, J.D. Beaton, J.H. Havlin. 1993. Soil fertility and fertilizers. MacMillan, New York.

Turgeon, A.J. 1991. Turfgrass management. Prentice Hall, Englewood Cliffs, N.J.

Wilkinson, J.F. and J.B. Beard. 1975. Anatomical responses of 'Merion' kentucky bluegrass and 'Pennlawn' red fescue at reduced light intensities. Crop Sci. 15:189-194.

Wu, L., D. Huff, and W.B. Davis. 1985. Tall fescue turf performance under a tree shade. HortScience $20: 281-282$. 